\title{
Physiological Responses of Pepper to Salinity and Drought
}

\author{
Stefania De Pascale, ${ }^{1}$ Celestino Ruggiero, ${ }^{2}$ and Giancarlo Barbieri ${ }^{3}$ \\ Department of Agricultural Engineering and Agronomy, University of Naples Federico II, Via Università \\ 100, 80055 Portici (NA), Italy
}

\author{
Albino Maggio ${ }^{4}$ \\ ENEA-National Center of Energy, Environment and Innovative Technology, C.R. Trisaia, S.S. Jonica Km \\ 419-500, 75026 Rotondella (MT), Italy
}

\begin{abstract}
ADDITIONAL INDEX wORDs. Capsicum annuum, gas exchanges, ion content, leaf and root water potentials, salt stress, drought
\end{abstract} stress

\begin{abstract}
Production of vegetable crops can be limited by saline irrigation water. The variability of crop salt tolerance under different environmental conditions requires species-specific and environment-specific field evaluations of salt tolerance. Data on field performances of vegetable crops grown on soils that have been irrigated with saline water for many years are lacking. In this study we analyzed the long-term effect of irrigation with saline water on soil properties and on responses of field-grown pepper (Capsicum annuum $\mathrm{L}$.) plants in these soils. Yield, gas exchanges, water relations, and solute accumulation were measured in plants grown under three different irrigation treatments: a nonsalinized control $\left(\mathbf{E C}_{\mathrm{w}}=\mathbf{0 . 5} \mathrm{dS} \cdot \mathrm{m}^{-1}\right)$ and two concentrations of commercial sea salt, corresponding to $\mathrm{EC}_{\mathrm{w}}$ of 4.4 and $8.5 \mathrm{dS} \cdot \mathrm{m}^{-1}$, respectively. In addition, a nonwatered drought stress treatment was included. Irrigation water with an EC of $4.4 \mathrm{dS} \cdot \mathrm{m}^{-1}$ resulted in $46 \%$ reduction in plant dry weight (leaves plus stem) and $25 \%$ reduction in marketable yield. Increasing the electrical conductivity of the irrigation water to $8.5 \mathrm{dS} \cdot \mathrm{m}^{-1}$ caused a $34 \%$ reduction in plant dry weight and a $58 \%$ reduction in marketable yield. Leaf and root cellular turgor and net $\mathrm{CO}_{2}$ assimilation rates of leaves in salt-stressed plants decreased along with a reduction in leaf area and dry matter accumulation. High concentrations of $\mathrm{Na}^{+}$and $\mathrm{Cl}^{-}$in the irrigation water did not significantly alter the level of $\mathrm{K}^{+}$in leaves and fruit. In contrast, drought stressed plants had higher concentrations of leaf $\mathrm{K}^{+}$compared to well watered control plants. These results indicate that $\mathrm{Na}^{+}$and $\mathrm{K}^{+}$may play similar roles in maintaining cellular turgor under salinity and drought stress, respectively. The regulation of ion loading to the shoots was most likely functionally associated with physiological modifications of the root/shoot ratio that was substantially smaller in salinized vs. drought stressed plants. From an agronomic perspective, irrigation with moderately saline water $\left(4.4 \mathrm{dS} \cdot \mathrm{m}^{-1}\right)$ it is recommendable, compared to no irrigation, to obtain an acceptable marketable yield in the specific environment considered.
\end{abstract}

In many coastal areas of the Mediterranean, vegetable crops are often unavoidably irrigated with saline water, which causes both yield reduction and damage to the soil's physicochemical properties (Biswas, 1993; Flowers, 1999). Salinity-induced reductions in yield are generally caused by ion toxicity (Niu et al., 1995), hyperosmotic stress (Yancey et al., 1982), and/or nutritional imbalance (Cramer et al. 1987; Liu and Zhu, 1998). The relative degree of each of these stresses caused by different salinity levels and their effects on crop production are not clearly understood. Salinity can cause membrane destabilization (Hasegawa et al., 2000), inhibition of the photosynthetic machinery (Munns and Termaat, 1986), nutrient imbalance (Munns, 1993), and irreversible damage to plant cells and tissues (Meyer and Boyer, 1981). After an initial loss of cellular turgor, saltstressed plants can osmotically adjust to the decrease in external water potential by compartmentalizing toxic ions in the vacuole and by synthesizing compatible solutes in the cytoplasm (Hasegawa et al., 2000). In addition, activation of the reactive oxygen scavenging system and regulation of cell growth rate can occur (Binzel et al., 1985; Long et al., 1994; Maggio et al.,

Received for publication 16 Apr. 2002. Accepted for publication 20 Aug. 2002. We would like to thank Robert Joly and Jim Syvertsen for critically reading the manuscript. This research was funded by MURST (Italian Ministry of University, Science and Technology), PRIN Compatibilità ambientale e qualificazione delle produzioni nei principali sistemi orticoli nazionali.

${ }^{1}$ Professor.

${ }^{4}$ Senior scientist, corresponding author.

${ }^{2}$ Full professor.

${ }^{3}$ Full professor. 2002b). Such metabolic responses allow acclimation to osmotically unfavorable environments but can decrease final crop yield. Generally, plants grown in saline environments are smaller in size, have fewer and smaller leaves, have increased root/shoot ratios, and have smaller fruit (Greenway and Munns, 1980).

Plant response to saline water can vary greatly depending on meteorological conditions, soil type (Laüchli and Epstein, 1990), species, cultivar (Rhoades et al., 1992), developmental stage (Cramer and Bowman, 1991; Yeo et al., 1991), the irrigation system, time interval between irrigations, amount of water distributed (Barbieri, 1995), and time of exposure to saline water (Oster, 1994). Such variability suggests that environment- and species-specific assessments of plant salt tolerance are both required to obtain conclusive information regarding the cultivation of a certain species using saline water of a specific concentration. Pepper (Capsicum annuиm), for instance, is very sensitive to drought stress and is moderately sensitive to salt stress (Ayers and Westcot, 1989; Meiri and Shalhevet, 1973; Rhoades et al., 1992). However, most of the available data on the effect of salinity on pepper (and other vegetables crops) are limited to growth in hydroponic systems or commercial substrates that have been exposed to salinity for a short period of time (Fernandez et al., 1977). In contrast, soils that have been irrigated with saline water for many years will likely have undergone substantial modifications of their physicochemical properties. Such modifications, which may significantly affect plant response to saline irrigation, cannot be easily reproduced in controlled environments or using substrates other than soil. Based on these considerations, we started a project in 1988 to evaluate long-term effects 
Table 1. Organic matter (OM, g/100 g soil), total nitrogen ( $\mathrm{N}, \mathrm{g} / 100 \mathrm{~g}$ soil), $\mathrm{pH}$, exchangeable cations (meq/100 g soil), and ESP (exchangeable sodium percentage) in the 0 to $30 \mathrm{~cm}$ soil layer at the beginning of the experiment

\begin{tabular}{lcccccrrr}
\hline \hline Treatment & $\mathrm{OM}$ & $\mathrm{N}$ & $\mathrm{pH}$ & $\mathrm{Na}^{+}$ & $\mathrm{K}^{+}$ & $\mathrm{Ca}^{2+}$ & $\mathrm{Mg}^{2+}$ & $\mathrm{ESP}^{-}$ \\
\hline NSC-DST & 1.44 & 0.104 & 7.12 & 0.38 & 0.75 & 12.58 & 3.06 & 2.27 \\
SW1 & & & & 1.5 & 1.48 & 9.74 & 2.29 \\
SW2 & 1.14 & 0.085 & 7.94 & 45.9 & 8.14 & 7.13 & 1.45 & 73.30 \\
\hline
\end{tabular}

Table 2. Water content (\% in volume) at field capacity determined in situ (FC) and water content at $-1.5 \mathrm{MPa}$ determined using a pressure plate (WP) in 0 to 30 and 0 to $60 \mathrm{~cm}$ soil layers as affected by long term irrigation with saline water. NSC $=$ nonsalinized control; DST $=$ drought stress treatment; $\mathrm{SW} 1=4.4 \mathrm{dS} \mathrm{m}{ }^{-1} ; \mathrm{SW} 2=8.5 \mathrm{dS} \mathrm{m}^{-1}$.

\begin{tabular}{|c|c|c|c|c|c|c|}
\hline \multirow{2}{*}{$\begin{array}{l}\text { Soil layer } \\
(\mathrm{cm})\end{array}$} & \multicolumn{2}{|c|}{ NSC-DST } & \multicolumn{2}{|c|}{ SW1 } & \multicolumn{2}{|c|}{ SW2 } \\
\hline & $\mathrm{FC}$ & WP & $\mathrm{FC}$ & WP & $\mathrm{FC}$ & WP \\
\hline $0-30$ & 35.5 & 17.5 & 34.7 & 16.8 & 33.9 & 16.6 \\
\hline $30-60$ & 35.9 & 17.5 & 35.3 & 17.6 & 34.8 & 16.6 \\
\hline
\end{tabular}

of irrigation with saline water on soil properties and yield of various vegetable crops. Since then (1988), the same experimental field has been irrigated with saline water (De Pascale and Barbieri, 1995). In 1997, as part of this project, we evaluated yield and physiological responses of pepper using irrigation water with three salinity levels. The underlying hypothesis was that a moderately saline irrigation is better than no irrigation to optimize yield in the specific environment considered. The main objectives of this study were 1) to evaluate water relations, mineral nutrition, net gas exchanges, growth and yield as responses to salinity stress and irrigation; 2) to compare effects of drought stress with salinity stress on these physiological responses; 3) to help growers decide if they should use poor quality water for irrigation.

\section{Materials and Methods}

Cultural conditions. 'Laser' pepper (Capsicum annuum L.) plants were transplanted when they had two fully expanded leaves on 12 June 1997 from Styrofoam containers (kept in the greenhouse) into a field of a clay-loam soil, (42\% sand, $27 \%$ loam, $31 \%$ clay, and trace amounts of lime) that had been irrigated for 9 years with saline water, at the University of Naples agronomy farm (lat. $43^{\circ} 31^{\prime} \mathrm{N}$, long. $14^{\circ} 58^{\prime} \mathrm{E}$ ). The chemical and water content properties of the soil at the beginning of the experiment are reported in Tables 1 and 2, respectively. On each experimental plot of $33 \mathrm{~m}^{2}, 110$ seedlings were placed $0.33 \mathrm{~m}$ apart within rows and $0.9 \mathrm{~m}$ between rows. Before transplanting, $100 \mathrm{~kg} \cdot \mathrm{ha}^{-1}$ of $\mathrm{N}$ $\left[\left(\mathrm{NH}_{4}\right)_{2} \mathrm{SO}_{4}\right], 51 \mathrm{~kg} \cdot \mathrm{ha}^{-1}$ of $\mathrm{P}$ (mineral superphosphate), and 82 $\mathrm{kg} \cdot \mathrm{ha}^{-1}$ of $\mathrm{K}\left(\mathrm{K}_{2} \mathrm{SO}_{4}\right)$ were applied to the soil. Subsequently, plants were fertilized with two additional applications of 40 $\mathrm{kg} \cdot \mathrm{ha}^{-1}$ of $\mathrm{N}\left(\mathrm{NH}_{4} \mathrm{NO}_{3}\right)$ on 30 June and on 21 July, respectively. Rainfall throughout the growing period was $333 \mathrm{~m}^{3} \cdot \mathrm{ha}^{-1}$ concentrated in the third week of August and mean daily air temperature was between 21 and $26^{\circ} \mathrm{C}$.

IRRIGATION TREATMENTS. Four irrigation/salinity treatments were used: a nonsalinized control $\left(\mathrm{NSC} ; \mathrm{EC}_{\mathrm{w}}=0.5 \mathrm{dS} \cdot \mathrm{m}^{-1}\right)$, two concentrations of commercial sea salt, SW1 and SW2, corresponding to $\mathrm{EC}_{\mathrm{w}}=4.4 \mathrm{dS} \cdot \mathrm{m}^{-1}$ and $\mathrm{EC}_{\mathrm{w}}=8.5 \mathrm{dS} \cdot \mathrm{m}^{-1}$, respectively and a drought stress treatment (DST), which received no irrigation after 12 July. Average osmotic potentials of the irrigation water were $-0.02,-0.22,-0.35 \mathrm{MPa}$ for the NSC, SW1 and SW2 treatments, respectively. Saline water was obtained by adding commercial sea salt $\left(\mathrm{Na}^{+} 12.3, \mathrm{~K}^{+} 3.8, \mathrm{Ca}^{2+} 0.02, \mathrm{Mg}^{2+} 0.04, \mathrm{Cl}^{-}\right.$
14.4, $\left.\mathrm{SO}_{4}{ }^{2-} 0.03 \mathrm{~mol} \cdot \mathrm{kg}^{-1}\right)$ to the irrigation water $\left(\mathrm{Na}^{+} 0.53, \mathrm{~K}^{+}\right.$ $0.05, \mathrm{Ca}^{2+} 1.55, \mathrm{Mg}^{2+} 0.84, \mathrm{Cl}^{-} 0.38, \mathrm{SO}_{4}{ }^{2-} 0.15, \mathrm{HCO}_{3}^{-} 4.73$ $\mathrm{mol} \cdot \mathrm{m}^{-3}$ ). Addition of commercial sea salt (instead of pure $\mathrm{NaCl}$ ) allowed us to reproduce closely the sea water contamination of the irrigation water that often occurs in coastal areas of southern Italy (De Pascale and Barbieri, 1995). To ensure the establishment of the seedlings, four $150 \mathrm{~m}^{3} \cdot \mathrm{ha}^{-1}$ irrigations $\left(600 \mathrm{~m}^{3} \cdot \mathrm{ha}^{-1}\right.$ total) of nonsalinized water were applied from transplanting to beginning of the treatments (17 July). Saline irrigation was initiated on 17 July and continued at 5-d intervals, except in the drought stress treatment. The amount of water applied at each irrigation was equal to the net evaporation between two irrigation events as determined using a Class A pan evaporimeter. A pan coefficient of one was used for the entire growing season to include a leaching fraction in the total volume of water applied at each irrigation event (Hoffman, 1990). The estimated water consumption was based on a nonstressed crop so all treatments received the same amount of water. However since crop growth was reduced under stress, the transpiration $(\mathrm{T})$ was reduced too. Therefore, salt-treated plants actually received higher leaching fractions compared to nonstressed plants. Water was distributed via drip irrigation. The total amount of water applied from the beginning of the treatments to harvest was $4050 \mathrm{~m}^{3} \cdot \mathrm{ha}^{-1}$.

ExPERIMENTAL DESIGN. In 1988, when the long-term salt tolerance assessment project was originally initiated, the experimental layout was a randomized block design replicated three times. Each block included four treatments: NSC, SW1, SW2, and DST. Since the objective of this study was to investigate longterm effects of salinization, the salinity treatments, which had been randomly assigned within each block in 1988, had to be reassigned to the same experimental field plots in each of the following years. Therefore, since 1988, each experimental plot has received the same EC irrigation water. Data were analyzed by ANOVA and means were compared by duncan's multiple range test.

WATER RELATIONS, GROWTH, AND YIELD MEASUREMENTS. Plant water relations were measured at 7-d intervals, beginning at $40 \mathrm{~d}$ after transplanting (DAT). Total water potential $\left(\Psi_{\mathrm{w}}\right)$ was measured between 1200 and 1300 HR on tissue disks removed from the first uppermost fully expanded, healthy leaves of nine plants per treatment (three per block) and also on excised segments $(8 \mathrm{~cm})$ of secondary roots taken from nine plants per treatment (three per block) in the 0 to $25 \mathrm{~cm}$ soil layer using a thermocouple psychrometer type B (Ruggiero et al., 1999; Slavik, 1974), at $29{ }^{\circ} \mathrm{C}$ 
(Boyer and Knipling, 1965). For statistical analysis, the mean value of three plants from each block was considered. After water potential was measured, leaves and roots were frozen at $-20{ }^{\circ} \mathrm{C}$, while still in the psychrometer chamber, and then thawed for $\Psi_{\mathrm{p}}$ measurements. Turgor potential $\left(\Psi_{\mathrm{p}}\right)$ was calculated as the difference between $\Psi_{w}$ and $\Psi_{\pi}($ Hsiao, 1973). Leaf osmotic adjustment (OA) was calculated according to the formula $\Psi_{\pi}^{100} \mathrm{~V}^{100}-\Psi_{\pi} \mathrm{V}$, where $\Psi_{\pi}^{100}$ and $V^{100}$ are osmotic potential and water content, respectively, of fully hydrated leaf samples, after floating leaf disks on distilled water at $20^{\circ} \mathrm{C}$ in a dark chamber for $24 \mathrm{~h} . \Psi_{\pi}$ and $\mathrm{V}$ are osmotic potential and water content, respectively, of nonhydrated leaf samples. $\mathrm{V}^{100}$ was approximated by the corresponding relative water content (RWC) calculated according to the equation: $\mathrm{RWC}=100 \times(\mathrm{FW}-\mathrm{DW}) /(\mathrm{TW}-\mathrm{DW})$. Turgid weight (TW) was determined after floating leaf discs on distilled water at $20^{\circ} \mathrm{C}$ in a dark chamber for $24 \mathrm{~h}$, and dry weight (DW) was determined after oven drying at $75^{\circ} \mathrm{C}$ for $48 \mathrm{~h}$. On the hydrated leaf disks used for turgid weight measurements, $\Psi_{\pi}^{100}$ was measured (Turner, 1981). Root and leaf bulk elastic modulus ( $\varepsilon$ ) were calculated according to the relationship: $\mathrm{d} \Psi_{\mathrm{p}} / \mathrm{d} \Psi_{\mathrm{t}}=\varepsilon /(\varepsilon$ $-\Psi_{\pi}$ ), where $\Psi_{\mathrm{p}}$ is the leaf pressure potential, $\Psi_{\mathrm{t}}$ is the total leaf water potential and $\Psi_{\pi}$ is the leaf osmotic potential (Morgan, 1984). Specifically, $\varepsilon$ was calculated by rearranging the equation as follows: $\varepsilon=\Psi_{\pi}\left(\mathrm{d} \Psi_{\mathrm{p}} / \mathrm{d} \Psi_{\mathrm{t}}\right) /\left(\mathrm{d} \Psi_{\mathrm{p}} / \mathrm{d} \Psi_{\mathrm{t}}-1\right)$. For each treatment and for each date, the term $\mathrm{d} \Psi_{\mathrm{p}} / \mathrm{d} \Psi_{\mathrm{t}}$ was calculated as the slope of the linear relationship between leaf pressure potential and leaf water potentials measured at midday.

At about 7-d intervals, net $\mathrm{CO}_{2}$ assimilation rate $(A)$, stomatal conductance $\left(g_{s}\right)$, and transpiration $(E)$ were measured between 1200 and $1300 \mathrm{HR}$ on the first uppermost expanded leaves of nine plants per treatment using a portable photosynthesis system (LI6200; LI-COR Inc., Lincoln, Nebr.) with a $275 \mathrm{~cm}^{3}$ leaf chamber. Water use efficiency (WUE) was calculated as the ratio $A / E$. During the measurements, mean leaf temperature was $34.9 \pm 2{ }^{\circ} \mathrm{C}$ [ranging between $30.9^{\circ} \mathrm{C}$ (NSC) and 38.2 (DST and SW2)], mean VPD was $2.6 \pm 0.8 \mathrm{kPa}$, and mean PPFD was $1641 \pm 227 \mathrm{mmol} \cdot \mathrm{m}^{-2} \cdot \mathrm{s}^{-1}$. Leaf area was measured using an area meter (LI-3000). Fresh weight and dry weight (after drying at $60^{\circ} \mathrm{C}$ until steady weight) were measured separately for leaves, stems, and fruit. The lengths of root systems were estimated according to Newman (1966). Soil

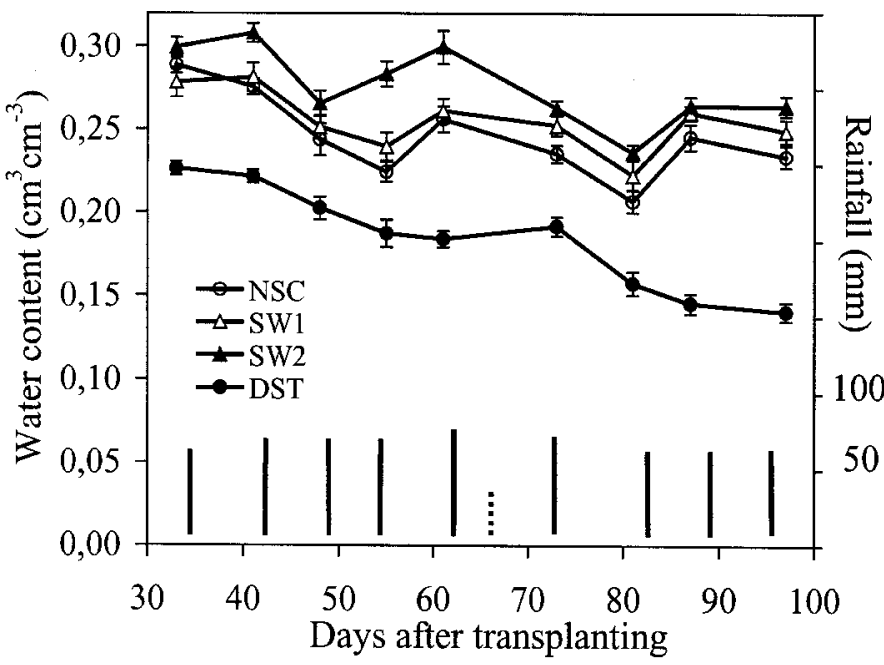

Fig. 1. Soil water content of samples taken before each irrigation event (solid bars at the bottom $=$ applied water; dotted line $=$ rain). Data points are means $\pm \mathrm{SE}$ of nine soil samples per treatment $\left(\mathrm{NSC}=\right.$ nonsalinized control; $\mathrm{SW} 1=4.4 \mathrm{dS} \cdot \mathrm{m}^{-}$ '; $\mathrm{SW} 2=8.5 \mathrm{dS} \cdot \mathrm{m}^{-1}$; DST $=$ drought stress treatment). and root samples (from the same nine plants used for gas exchange analysis) were taken at $30-\mathrm{cm}$ intervals in the 0 to $90 \mathrm{~cm}$ soil layer. Roots were separated from soil particles by treating each sample with a $10 \%$ (w/v) Calgon wetting solution $(85 \%$ sodium hexametaphosphate, $15 \%$ sodium carbonate; Carlo Erba OTC-Pharmacia, Milan, Italy) and subsequently passing roots through a $0.2 \mathrm{~mm}$ metal screen. Before each irrigation event, soil water content was measured at $15,45,75$, and $90 \mathrm{~cm}$ depth using the gravimetric method after drying the soil samples at $105^{\circ} \mathrm{C}$ until steady weight. Electrical conductivity of saturated soil extracts (at $25^{\circ} \mathrm{C}$ ) was measured monthly at $15,45,75$, and $90 \mathrm{~cm}$ depth. Fruit harvest was begun on 18 Aug. 1997 and ended on 19 Sept. 1997; fruit were counted, weighed and judged for their marketability (the nonmarketable yield included fruit having blossom-end rot, injuries or weight $<50 \mathrm{~g}$ ).

ION ANALYSIS. At the end of harvest, concentrations of $\mathrm{N}, \mathrm{P}, \mathrm{K}^{+}$, $\mathrm{Ca}^{2+}, \mathrm{Mg}^{2+}, \mathrm{Na}^{+}, \mathrm{Cl}^{-}$and $\mathrm{S}$ were measured in dried and ground tissue from fully expanded nonsenesced leaves and ripe fruit of nine plants per treatment (three plants per block) by atomic absorption spectrophotometry or by a colorimetric assay (Walinga et al., 1995). Total $\mathrm{N}$ was determined using the Kjeldhal method. Sulfur was analyzed by inductively coupled plasma atomic emission (ICP-ES) (ELAN 9000; Perkin Elmer-Sciex, Wellesley, Mass.).

\section{Results}

SoIL WATER CONTENT. The soil water content before each irrigation event decreased during the growing season from an average of $26 \%$ in the irrigated plots and $23 \%$ in the DST at 33 DAT to $25 \%$ in the irrigated plots and $18 \%$ in the DST (Fig. 1). The mean electrical conductivity of the saturated soil extracts $\left(\mathrm{EC}_{\mathrm{e}}\right)$ along the soil profile $(0$ to $90 \mathrm{~cm})$ during the entire growing season were about $2,2.6,3.5$, and $6 \mathrm{dS} \cdot \mathrm{m}^{-1}$ for the NSC, DST, $\mathrm{SW} 1$, and SW2, respectively. Therefore they remained relatively constant.

Plant-water Relations. Leaf and $\operatorname{root} \Psi_{\mathrm{w}}, \Psi_{\mathrm{p}}, \Psi_{\pi}$, and OA were higher in NSC and SW1 plants compared to DST and SW2 plants (Table 3 ). In contrast, $\varepsilon$ was lower in NSC and SW1 plants compared to DST and SW2 plants (Table 3). For all these parameters, reductions were proportional to the salt concentration in the irrigation water. Over the entire growth season, irrigating with an $\mathrm{EC}_{\mathrm{w}}$ of $8.5 \mathrm{dS} \cdot \mathrm{m}^{-1}(\mathrm{SW} 2)$ and not irrigating (DST) affected plant water relations similarly (Table 3 ).

LEAF GAS EXCHANGES AND WATER USE EFFICIENCY. In line with the water relation results, net $\mathrm{CO}_{2}$ assimilation $(A)$ and transpiration $(E)$ rates were significantly lower in DST, SW1 and SW2 plants relative to NSC plants (Table 4). The net $\mathrm{CO}_{2}$ assimilation rate decreased at increasing salinity, whereas no differences in terms of transpiration rates and stomatal conductance were detected between salinized and drought stressed plants. Consequently, the instantaneous water use efficiency (WUE), estimated as the ratio between net $\mathrm{CO}_{2}$ assimilation and transpiration rates, was significantly higher in NSC and SW1 compared to SW2 and DST plants.

ROOT GROWTH. Root density proportionally decreased at increasing salt concentration in the irrigation water (Fig. 2). Nonsalinized control plants had the greatest average root density, while DST plants had the least. Differences among treatments were not significant at the 60 to $90 \mathrm{~cm}$ depth, possibly due to low root densities, smaller EC differences among treatments, and reduced soil aeration. Regardless of the salt treatment, root 
Table 3. Water potential $\left(\Psi_{\mathrm{w}}\right)$, osmotic potential $\left(\Psi_{\pi}\right)$, and turgor potential $\left(\Psi_{\mathrm{p}}\right)$, relative water content (RWC), osmotic adjustment $(\mathrm{OA})$, and modulus of elasticity $(\varepsilon)$ in pepper leaves and roots in response to irrigation treatments $\left(\mathrm{NSC}=\right.$ nonsalinized control; $\mathrm{SW} 1=4.4 \mathrm{dS} \cdot \mathrm{m}^{-1}$; $\mathrm{SW} 2$ $=8.5 \mathrm{dS} \cdot \mathrm{m}^{-1} ; \mathrm{DST}=$ drought stress treatment). Values are means of 24 samples (each sample was the mean value of three plants per block).

\begin{tabular}{|c|c|c|c|c|c|c|}
\hline Treatment & $\begin{array}{c}\Psi_{\mathrm{w}} \\
(\mathrm{MPa})\end{array}$ & $\begin{array}{c}\Psi_{\pi} \\
(\mathrm{MPa})\end{array}$ & $\begin{array}{c}\Psi_{\mathrm{p}} \\
(\mathrm{MPa})\end{array}$ & $\begin{array}{c}\text { RWC } \\
(\%)\end{array}$ & $\begin{array}{c}\mathrm{OA} \\
(\mathrm{MPa})\end{array}$ & $\begin{array}{c}\varepsilon \\
(\mathrm{MPa})\end{array}$ \\
\hline \multicolumn{7}{|l|}{ Leaves } \\
\hline DST & $-1.46 c^{\mathrm{z}}$ & $-1.63 \mathrm{c}$ & $0.17 \mathrm{c}$ & $96.0 \mathrm{~b}$ & $0.30 \mathrm{a}$ & $3.62 \mathrm{a}$ \\
\hline NSC & $-0.95 \mathrm{a}$ & $-1.38 \mathrm{a}$ & $0.43 \mathrm{a}$ & 96.8 a & $0.20 \mathrm{~b}$ & $3.09 \mathrm{~b}$ \\
\hline SW1 & $-1.21 \mathrm{~b}$ & $-1.49 \mathrm{ab}$ & $0.28 \mathrm{~b}$ & $96.9 \mathrm{a}$ & $0.24 \mathrm{~b}$ & $3.33 \mathrm{ab}$ \\
\hline SW2 & $-1.41 \mathrm{c}$ & $-1.60 \mathrm{c}$ & $0.19 \mathrm{c}$ & $96.5 \mathrm{ab}$ & $0.29 \mathrm{a}$ & $3.57 \mathrm{a}$ \\
\hline \multicolumn{7}{|l|}{ Roots } \\
\hline DST & $-0.69 \mathrm{c}$ & $-0.88 \mathrm{c}$ & $0.19 \mathrm{c}$ & $\mathrm{NM}^{\mathrm{y}}$ & NM & $0.51 \mathrm{a}$ \\
\hline NSC & $-0.43 \mathrm{a}$ & $-0.71 \mathrm{a}$ & $0.28 \mathrm{a}$ & & & $0.44 \mathrm{a}$ \\
\hline SW1 & $-0.54 \mathrm{~b}$ & $-0.76 \mathrm{ab}$ & $0.22 \mathrm{~b}$ & & & $0.48 \mathrm{a}$ \\
\hline SW2 & $-0.67 \mathrm{c}$ & $-0.84 \mathrm{bc}$ & $0.17 \mathrm{c}$ & & & $0.53 \mathrm{a}$ \\
\hline
\end{tabular}

${ }^{\mathrm{z}}$ Mean separation in columns by duncan's multiple range test at $P \leq 0.05$.

yNot measured.

Table 4. Net $\mathrm{CO}_{2}$ assimilation rate $(A)$, transpiration rate $(E)$, stomatal conductance $\left(g_{s}\right)$, and water use efficiency (WUE) of pepper plants in response to irrigation treatments ( $\mathrm{NSC}=$ nonsalinized control; $\mathrm{SW} 1=4.4 \mathrm{dS} \cdot \mathrm{m}^{-1} ; \mathrm{SW} 2=8.5 \mathrm{dS} \cdot \mathrm{m}^{-1} ; \mathrm{DST}=$ drought stress treatment). Values are means of nine samples (each sample was the mean value of three plants per block).

\begin{tabular}{|c|c|c|c|c|}
\hline Treatment & $\begin{array}{c}A \\
\left(\mu \mathrm{mol} \mathrm{CO}_{2} / \mathrm{m}^{2} / \mathrm{s}\right)\end{array}$ & $\begin{array}{c}E \\
\left(\mathrm{mmol} \mathrm{H}_{2} \mathrm{O} / \mathrm{m}^{2} / \mathrm{s}\right)\end{array}$ & $\begin{array}{c}g_{s} \\
\left(\mathrm{~mol} \cdot \mathrm{m}^{-2} \cdot \mathrm{s}^{-1}\right)\end{array}$ & $\begin{array}{l}\text { WUE } \\
(A / E)\end{array}$ \\
\hline$\overline{\mathrm{DST}}$ & $5.3 \mathrm{c}^{\mathrm{z}}$ & $8.2 \mathrm{~b}$ & $0.40 \mathrm{~b}$ & $0.64 \mathrm{c}$ \\
\hline NSC & $14.0 \mathrm{a}$ & $11.2 \mathrm{a}$ & $0.75 \mathrm{a}$ & $1.25 \mathrm{a}$ \\
\hline SW1 & $11.2 \mathrm{~b}$ & $9.5 \mathrm{~b}$ & $0.41 \mathrm{~b}$ & $1.18 \mathrm{a}$ \\
\hline SW2 & $6.5 \mathrm{c}$ & $8.2 \mathrm{~b}$ & $0.40 \mathrm{~b}$ & $0.79 \mathrm{~b}$ \\
\hline
\end{tabular}

${ }^{\bar{z}}$ Mean separation in columns by duncan's multiple range test at $P \leq 0.05$.

densities reached their maximum values at the end of August (at day 60 after transplanting, during the fruit enlargement) and decreased $\approx 50 \%$ at each depth considered along the soil profile. Compared to NSC plants, the leaf surface area/root length ratios of SW1 and SW2 plants were 10\% and 25\% smaller, respectively, and 22\% smaller for the DST plants (data not shown). Root density was correlated with root cellular turgor $\left(r=0.787^{* *}\right)$ and leaf surface area $\left(r=0.877^{* *}\right)$.

Plant growth and fruit yield. Salt treatment decreased leaf growth (Table 5). The smallest plant leaf areas were measured in SW1 and SW2 plants, where it was $\approx 55 \%$ of NSC plants. The decrease in leaf area of SW2 plants was attributable mainly to a decrease in leaf number as opposed to a reduction in leaf size. The specific leaf weights (SLW), which were similar in irrigated plants, were significantly lower than in drought plants. The root/ shoot ratio (expressed as root length per leaf area unit) significantly increased with salinity whereas it was remarkably higher in drought plants compared to both NSC and salinized plants, suggesting that stress acclimation may involve different partitioning of photosynthates in water and drought stressed plants. We observed a strong correlation between leaf surface area and turgor pressure $\left(r=0.927^{* *}\right)$. Dry matter accumulation and net $\mathrm{CO}_{2}$ assimilation rate were also positively correlated $\left(r=0.877^{* *}\right)$. Salinity reduced more than drought the fruit dry weight/plant (Table 5). In contrast, the average fruit weight, which was also reduced under drought or saline treatments, was smaller in DST relative to salinized plants (Table 6). The number of fruit per plant was not affected by salt treatments or the absence of irrigation. Decreases in average fruit weight significantly decreased the marketable yield. The marketable yield per plant was correlated with the leaf surface area $\left(r=0.959^{* *}\right)$.

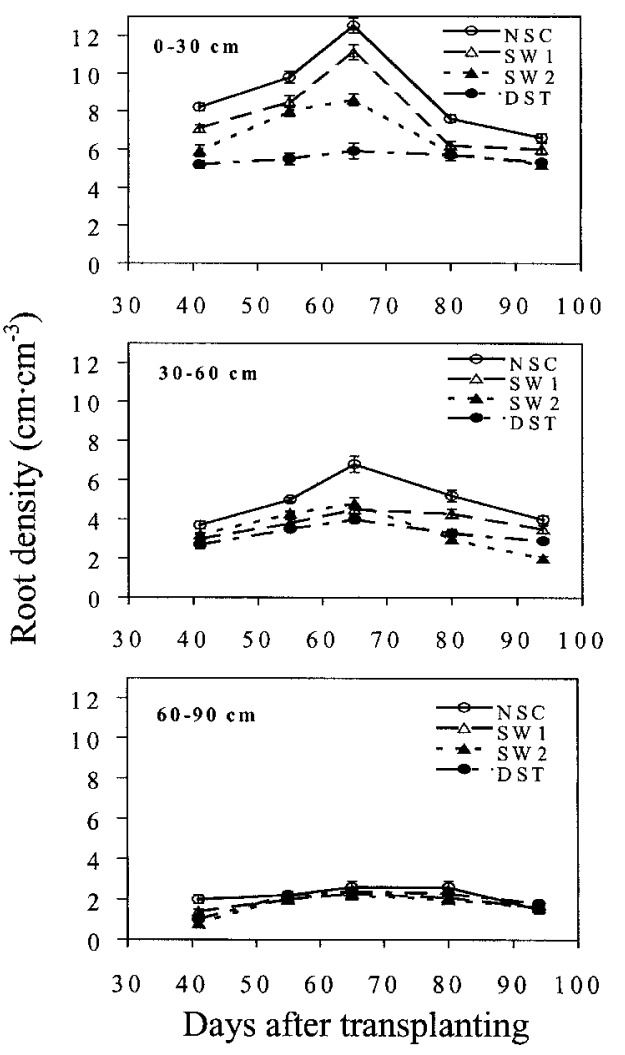

Fig. 2. Root density in pepper plants (root length per volume of soil) in response to irrigation treatments $\left(\mathrm{NSC}=\right.$ nonsalinized control; $\mathrm{SW} 1=4.4 \mathrm{dS} \cdot \mathrm{m}^{-1} ; \mathrm{SW} 2=8.5$ $\mathrm{dS} \cdot \mathrm{m}^{-1} ; \mathrm{DST}=$ drought stress treatment) at soil depths of $0-30,30-60,60-90 \mathrm{~cm}$. Values are means \pm SE of nine plants per treatment (three plants per block). 
Table 5. Leaf area, number of leaves, dry weights, and specific leaf weight (SLW) in pepper plants at harvest in response to irrigation treatments (NSC $=$ nonsalinized control $; \mathrm{SW} 1=4.4 \mathrm{dS} \cdot \mathrm{m}^{-1} ; \mathrm{SW} 2=8.5 \mathrm{dS} \cdot \mathrm{m}^{-1} ; \mathrm{DST}=$ drought stress treatment). Values are means of nine plants (three plants per block).

\begin{tabular}{|c|c|c|c|c|c|c|c|c|}
\hline Treatment & $\begin{array}{c}\text { Total } \\
\text { leaf } \\
\text { area } \\
\left(\mathrm{m}^{2} / \text { plant }\right)\end{array}$ & $\begin{array}{c}\text { Avg } \\
\text { leaf } \\
\text { area } \\
\left(\mathrm{cm}^{2} / \mathrm{leaf}\right)\end{array}$ & $\begin{array}{c}\text { Leaves/ } \\
\text { plant }\end{array}$ & $\begin{array}{c}\text { Leaf } \\
\text { dry } \\
\text { wt } \\
\left(\mathrm{g} / \text { plant }^{-1}\right)\end{array}$ & $\begin{array}{c}\text { Stem } \\
\text { dry } \\
\text { wt } \\
\left(\mathrm{g} / \text { plant }^{-1}\right)\end{array}$ & $\begin{array}{c}\text { Fruit } \\
\text { dry } \\
\text { wt } \\
\text { (g/plant) }\end{array}$ & $\begin{array}{c}\text { SLW } \\
\left(\mathrm{mg} \cdot \mathrm{cm}^{-2}\right)\end{array}$ & $\begin{array}{l}\text { Root to } \\
\text { shoot } \\
\text { ratio } \\
\left(\mathrm{cm} \cdot \mathrm{cm}^{-2}\right)\end{array}$ \\
\hline$\overline{\mathrm{DST}}$ & $0.425 \mathrm{~b}^{\mathrm{z}}$ & $264 b$ & $16.1 \mathrm{a}$ & $27.6 \mathrm{~b}$ & $29.0 \mathrm{~b}$ & $104.4 \mathrm{~b}$ & $10.0 \mathrm{a}$ & $228 \mathrm{a}$ \\
\hline NSC & $0.581 \mathrm{a}$ & $320 \mathrm{a}$ & $18.2 \mathrm{a}$ & $40.8 \mathrm{a}$ & $41.8 \mathrm{a}$ & $117.4 \mathrm{a}$ & $6.9 \mathrm{~b}$ & $163 \mathrm{c}$ \\
\hline SW1 & $0.329 \mathrm{c}$ & $192 \mathrm{c}$ & $17.1 \mathrm{a}$ & $21.6 \mathrm{c}$ & $22.8 \mathrm{~b}$ & $86.9 \mathrm{c}$ & $7.7 \mathrm{~b}$ & $199 \mathrm{~b}$ \\
\hline SW2 & $0.321 \mathrm{c}$ & $292 \mathrm{ab}$ & $11.0 \mathrm{~b}$ & $29.4 \mathrm{~b}$ & $24.2 \mathrm{~b}$ & $91.5 \mathrm{c}$ & $7.8 \mathrm{~b}$ & $195 \mathrm{~b}$ \\
\hline
\end{tabular}

${ }^{\bar{z}}$ Mean separation in columns by duncan's multiple range test at $P \leq 0.05$.

Table 6. Yield parameters in pepper plants in response to irrigation treatments $\left(\mathrm{NSC}=\right.$ nonsalinized control; $\mathrm{SW} 1=4.4 \mathrm{dS} \cdot \mathrm{m}^{-1} ; \mathrm{SW} 2=$ $8.5 \mathrm{dS} \cdot \mathrm{m}^{-1}$; DST $=$ drought stress treatment). Values are means of nine plants (three plants per block).

\begin{tabular}{lcccc}
\hline \hline & $\begin{array}{c}\text { Total } \\
\text { yield }\end{array}$ & $\begin{array}{c}\text { Avg } \\
\text { fruit wt } \\
\text { Treatment }\end{array}$ & $\begin{array}{c}\text { Fruit/ } \\
\text { (kg fresh wt/plant) }\end{array}$ & $\begin{array}{c}\text { Marketable } \\
\text { yield } \\
\text { (kg/plant) }\end{array}$ \\
\hline DST & $0.63 \mathrm{c}^{\mathrm{z}}$ & $51.5 \mathrm{~d}$ & $12.5 \mathrm{a}$ & $0.32 \mathrm{~d}$ \\
NSC & $1.42 \mathrm{a}$ & $112.4 \mathrm{a}$ & $12.5 \mathrm{a}$ & $1.24 \mathrm{a}$ \\
SW1 & $1.16 \mathrm{~b}$ & $99.7 \mathrm{~b}$ & $12.5 \mathrm{a}$ & $0.94 \mathrm{~b}$ \\
SW2 & $0.72 \mathrm{c}$ & $65.2 \mathrm{c}$ & $11.8 \mathrm{a}$ & $0.52 \mathrm{c}$ \\
\hline
\end{tabular}

${ }^{\mathrm{z}}$ Mean separation in columns by duncan's multiple range test at $P \leq 0.05$.

LEAF AND FRUIT ION CONTENT. A significant increase in foliar concentration of $\mathrm{K}^{+}$and $\mathrm{S}$ was observed in drought stressed plants on both dry weight and leaf area bases, whereas an increase in $\mathrm{N}$ concentration was observed only on a leaf area basis. In contrast, salinity did not affect the concentration of $\mathrm{N}$ and $\mathrm{S}$ (Table 7). High salinity was associated with an increase in the concentration of $\mathrm{Ca}^{2+}$ in leaves and with a decrease in fruit. The concentrations of $\mathrm{Na}^{+}$and $\mathrm{Cl}^{-}$significantly increased in SW2 leaves and fruit.

\section{Discussion}

In areas where saline water is the only water available for irrigation, it is expected that a recurrent salinization of the soil will eventually modify its physicochemical properties, and consequently affect plant growth. Irrigation with an $\mathrm{EC}_{\mathrm{w}}$ of $4.4 \mathrm{dS} \cdot \mathrm{m}^{-1}$, which caused $46 \%$ and $25 \%$ reductions in plant dry weight (leaves plus stem) and marketable yield, respectively, may still be considered economically acceptable in certain Mediterranean areas (Barbieri, 1995). Doubling the EC of the irrigation water $\left(8.5 \mathrm{dS} \cdot \mathrm{m}^{-1}\right)$ resulted in a $34 \%$ reduction in plant dry weight and a $58 \%$ reduction in marketable yield, which is not considered to be economically acceptable.

To compare our results with available salt tolerance data for pepper (Rhoades et al., 1992), we expressed the relative yield in kilograms per plant. A yield reduction of $\approx 50 \%$ at an $\mathrm{EC}_{\mathrm{e}}$ of 6 $\mathrm{dS} \cdot \mathrm{m}^{-1}$ (corresponding to $\mathrm{EC}_{\mathrm{w}}$ of $8.5 \mathrm{dS} \cdot \mathrm{m}^{-1}$ ) was consistent with the one calculated using the Maas and Hoffman (1977) relationship $\left(\mathrm{EC}_{\mathrm{e}}=5.9 \mathrm{dS} \cdot \mathrm{m}^{-1}\right)$ based on the pepper threshold $\left(1.7 \mathrm{dS} \cdot \mathrm{m}^{-1}\right)$ and slope $\left.\left[12 \% \times \mathrm{dS} \cdot \mathrm{m}^{-1}\right)^{-1}\right]$ developed by Rhoades et al. (1992). In spite of the general use of the Maas-Hoffmann model to assess plant salt tolerance, the simple relationship between yield and root-zone salinity does not allow us to identify the critical physiological mechanisms underlying stress acclimation. Environmental and cultural variables may affect plant response to salinity (Hoffman, 1990; Rhoades et al., 1992). Soil aeration and efficient drainage, for instance, are factors that may substantially contribute to the maintenance of tolerable salinity levels in soil for pepper plants (Emerman and Dawson, 1996; Hachicha et al., 2000). Dalton et al. (1997 and 2000) recently discussed in detail the complexity of salt stress acclimation on a whole-plant basis

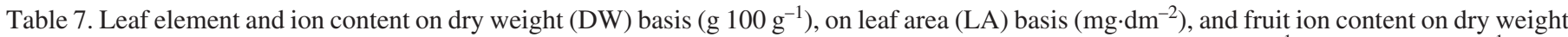
basis $(\mathrm{g} / 100 \mathrm{~g})$ of pepper plants in response to irrigation treatments $\left(\mathrm{NSC}=\right.$ nonsalinized control; $\mathrm{SW} 1=4.4 \mathrm{dS} \cdot \mathrm{m}^{-1} ; \mathrm{SW} 2=8.5 \mathrm{dS} \cdot \mathrm{m}^{-1} ; \mathrm{DST}$ $=$ drought). Values are means of nine plants (three plants per block).

\begin{tabular}{|c|c|c|c|c|c|c|c|c|}
\hline Treatment & $\mathrm{N}$ & $\mathrm{P}$ & $\mathrm{K}^{+}$ & $\mathrm{Ca}^{2+}$ & $\mathrm{Mg}^{2+}$ & $\mathrm{S}$ & $\mathrm{Na}^{+}$ & $\mathrm{Cl}^{-}$ \\
\hline \multicolumn{9}{|c|}{ Leaves (g/100 g DW) } \\
\hline DST & $3.67 \mathrm{a}^{\mathrm{z}}$ & $0.24 \mathrm{a}$ & $3.87 \mathrm{a}$ & $3.26 \mathrm{~b}$ & $0.67 \mathrm{a}$ & $0.41 \mathrm{a}$ & $0.07 \mathrm{~b}$ & $0.11 \mathrm{c}$ \\
\hline NSC & $3.63 \mathrm{a}$ & $0.33 \mathrm{a}$ & $3.42 \mathrm{~b}$ & $3.40 \mathrm{~b}$ & $0.72 \mathrm{a}$ & $0.31 \mathrm{~b}$ & $0.08 \mathrm{~b}$ & $0.10 \mathrm{c}$ \\
\hline SW1 & $3.36 \mathrm{a}$ & $0.20 \mathrm{a}$ & $3.33 \mathrm{~b}$ & $4.08 \mathrm{a}$ & $0.68 \mathrm{a}$ & $0.29 \mathrm{~b}$ & $0.11 \mathrm{~b}$ & $0.19 \mathrm{~b}$ \\
\hline SW2 & $3.20 \mathrm{a}$ & $0.25 \mathrm{a}$ & $2.99 \mathrm{~b}$ & $4.06 \mathrm{a}$ & $0.72 \mathrm{a}$ & $0.29 \mathrm{~b}$ & $0.29 \mathrm{a}$ & $0.36 \mathrm{a}$ \\
\hline \multicolumn{9}{|c|}{ Leaves $\left(\mathrm{mg} \mathrm{dm}^{-2} \mathrm{LA}\right)$} \\
\hline DST & $36.7 \mathrm{a}$ & $2.4 \mathrm{a}$ & $38.7 \mathrm{a}$ & $32.6 \mathrm{a}$ & $6.7 \mathrm{a}$ & $4.1 \mathrm{a}$ & $0.7 \mathrm{~b}$ & $1.0 \mathrm{~b}$ \\
\hline NSC & $23.7 \mathrm{~b}$ & $2.2 \mathrm{ab}$ & $24.4 \mathrm{~b}$ & $23.1 \mathrm{~b}$ & $4.8 \mathrm{~b}$ & $2.2 \mathrm{~b}$ & $0.5 \mathrm{~b}$ & $0.7 \mathrm{~b}$ \\
\hline SW1 & $26.8 \mathrm{~b}$ & $1.7 \mathrm{~b}$ & $26.6 \mathrm{~b}$ & $31.0 \mathrm{a}$ & $5.3 \mathrm{~b}$ & $2.3 \mathrm{~b}$ & $0.7 \mathrm{~b}$ & $1.2 \mathrm{~b}$ \\
\hline SW2 & $26.3 \mathrm{~b}$ & $2.2 \mathrm{ab}$ & $23.4 \mathrm{~b}$ & $31.1 \mathrm{a}$ & $5.8 \mathrm{ab}$ & $2.4 \mathrm{~b}$ & $2.1 \mathrm{a}$ & $2.6 \mathrm{a}$ \\
\hline \multicolumn{9}{|c|}{ Fruit (g $100 \mathrm{~g}^{-1} \mathrm{DW}$ ) } \\
\hline DST & $2.20 \mathrm{~b}$ & $0.38 \mathrm{a}$ & $1.26 \mathrm{a}$ & $0.12 \mathrm{ab}$ & $0.12 \mathrm{a}$ & $0.09 \mathrm{bc}$ & $0.03 \mathrm{~b}$ & $0.04 \mathrm{~b}$ \\
\hline NSC & $2.45 \mathrm{ab}$ & $0.38 \mathrm{a}$ & $1.13 \mathrm{a}$ & $0.18 \mathrm{a}$ & $0.13 \mathrm{a}$ & $0.12 \mathrm{ab}$ & $0.03 \mathrm{~b}$ & $0.05 \mathrm{~b}$ \\
\hline SW1 & $2.70 \mathrm{a}$ & $0.39 \mathrm{a}$ & $1.13 \mathrm{a}$ & $0.16 \mathrm{a}$ & $0.13 \mathrm{a}$ & $0.14 \mathrm{a}$ & $0.08 \mathrm{~b}$ & $0.11 \mathrm{~b}$ \\
\hline SW2 & $2.54 \mathrm{a}$ & $0.34 \mathrm{~b}$ & $1.27 \mathrm{a}$ & $0.07 \mathrm{~b}$ & $0.13 \mathrm{a}$ & $0.07 \mathrm{c}$ & $0.31 \mathrm{a}$ & $0.49 \mathrm{a}$ \\
\hline
\end{tabular}

${ }^{\mathrm{z}}$ Mean separation in columns by duncan's multiple range test at $P \leq 0.05$. 
and proposed an alternative index to evaluate plant salt tolerance, which does not correlate yield with root zone salinity, but rather with a measure of the dynamic process of salt accumulation in the shoot (Dalton et al., 2001; Maggio et al., 2002a).

The potential variability in plant response to salt stress is also evident in terms of plant water relations. Leaf and root water potentials, turgor potentials, osmotic potentials, and leaf gas exchange rates were negatively affected by salinity or drought. These results are consistent with those reported by Gunes et al. (1996), who found an increased stomatal resistance in salt-treated pepper plants and with those of Bethke and Drew (1992), who reported nonstomatal reduction of photosynthetic rates in saltstressed pepper plants. However, despite their use of higher salinity treatments $\left(50,100\right.$, and $150 \mathrm{~mol} \cdot \mathrm{m}^{-3} \mathrm{NaCl}$ in their experiments compared to $\approx 30$ and $60 \mathrm{~mol} \cdot \mathrm{m}^{-3} \mathrm{NaCl}$ in our experiment), Bethke and Drew (1992) did not observe any reduction in leaf cellular turgor. This result may be explained by the more severe stress experienced by plants grown in the field (our experiment) compared to plants grown in the greenhouse (their experiment).

The concentration of $\mathrm{Ca}^{2+}$ increased in leaves of salt treated plants on both a dry weight and a leaf area basis, whereas it increased only on a leaf area basis in drought stressed plants. Considering that the level of $\mathrm{Ca}^{2+}$ was significantly lower in salinized soils (Tables 1 and 2), possibly due to a greater leaching (Maas and Grattan, 1999), these results suggest that, in our experimental conditions, salt treated plants had an enhanced ability to take up $\mathrm{Ca}^{2+}$. The implication of $\mathrm{Ca}^{2+}$ and relative mechanisms mediating $\mathrm{Ca}^{2+}$ transport in salt stress acclimation has been well documented (Hasegawa et al., 2000; Liu and Zhu, 1998). In addition, the increased $\mathrm{Ca}^{2+}$ uptake might have prevented the appearance of blossom-end rot in pepper at moderate salinity (SW1) (Adams and Ho, 1995). However, at higher levels of stress (SW2 and DST plants), a reduced translocation of $\mathrm{Ca}^{2+}$ from leaves to fruit may have been one of the reasons for increased blossom-end rot in fruit (data not shown), (Maas and Grattan, 1999).

In contrast to other reports (Gomez et al., 1996; Gunes et al., 1996), the presence of $\mathrm{Na}^{+}$and $\mathrm{Cl}^{-}$in the solution in contact with the roots did not affect fruit concentrations of $\mathrm{K}^{+}$, the uptake of which is typically hindered by high concentrations of $\mathrm{Na}^{+}$ (Hasegawa et al., 2000), and it moderately inhibited the foliar concentration only at high salinity. Interestingly, analysis of salinized soil extracts revealed a significant increase in exchangeable $\mathrm{K}^{+}$compared to the nonsalinized control soil (Tables 1 and 2 ), which may have been sufficient to counteract partially the competition between $\mathrm{Na}^{+}$and $\mathrm{K}^{+}$uptake. The increases in $\mathrm{K}^{+}$and $\mathrm{Na}^{+}$concentrations, suggests that these ions may play similar roles in facilitating high turgor maintenance under drought and salt stress, respectively. The accumulation of $\mathrm{K}^{+}$and $\mathrm{Na}^{+}$ions was likely to be functionally associated with different root/shoot ratios observed in salinized vs. drought stressed plants. Droughted plants had the most expanded root system which most likely optimized water uptake by exploring a larger volume of soil. In this case, partitioning of photosynthates to favor the root system was detrimental to normal fruit growth $(65 \%$ of the fruit were classified as nonmarketable), yet it enhanced $\mathrm{K}^{+}$uptake resulting in leaf osmotic adjustment. The increase in leaf nitrogen content on leaf area basis observed in drought stressed plants is consistent with this hypothesis and with the assumption that water deficit may directly inhibit leaf expansion more than nutrient uptake (Chapin III, 1991). In contrast, the smaller root/shoot ratio observed in salinized vs. droughted plants may have been functionally associated with the need of salt stressed plants to restrict the uptake of toxic ions to the shoot while still maintaining high turgor and a positive growth rate (Dalton et al., 1997; Maggio et al., 2001). This may be accomplished by simultaneously reducing root vs. shoot development and activating specific metabolic pathways (i.e., osmolytes biosynthesis), both of which occur in saline environments (Gunes et al., 1996; Handa et al., 1986; Hayashi et al., 1997; Kavi Kishor et al., 1995; Maggio et al., 2001; Shen et al., 1997; Tarczynski et al., 1993; Yancey, 1994). The agronomic implication of these responses is that, at moderate water salinity, pepper plants are able to acclimate without excessively impairing marketable yields, relative to the nonsalinized control.

\section{Literature Cited}

Adams, P. and L.C. Ho. 1995. Uptake and distribution of nutrients in relation to tomato fruit quality. Acta Hort. 412:374-387.

Ayers, R.S. and D.W. Westcot. 1989. Water quality for agriculture. Irr. Drainage Paper 29 rev. 1. FAO, Rome.

Barbieri, G. 1995. Restrizione delle risorse idriche e strategie di irrigazione. Atti Accademia dei Georgofili. Ser. VII. vol. XLII. p. 589-600.

Bethke, P.C. and M.C. Drew. 1992. Stomatal and nonstomatal components to inhibition of photosynthesis in leaves of Capsicum annuum during progressive exposure to $\mathrm{NaCl}$ salinity. Plant Physiol. 99:219226.

Biswas, A.K. 1993. Water for agricultural development, opportunities and constraints. Int. J. Water Res. Dev. 9:3-12.

Binzel, M.L., P.M. Hasegawa, and R.A. Bressan. 1985. Adaptation of tobacco cells to NaCl. Plant Physiol. 79:118-125.

Boyer, J.S. and E.B. Knipling. 1965. Isopiestic technique for measuring leaf water potential with a thermocouple psychrometer. Proc. Nat. Acad. Sci. USA 54:1044-1051.

Chapin, III, F.S. 1991. Effects of multiple environmental stresses on nutrient availability and use, p. 277-290. In: H.A. Mooney, W.E. Winner, and E.J. Pell (eds.). Response of plants to multiple stresses. Academic Press, New York.

Cramer, G.R., J. Lynch, A. Läuchli, and E. Epstein. 1987. Influx of $\mathrm{Na}^{+}$, $\mathrm{K}^{+}$, and $\mathrm{Ca}^{2+}$ into roots of salt-stressed cotton seedlings. Plant Physiol. 83:510-516.

Cramer, G.R. and D.C. Bowman. 1991. Kinetics of maize leaf elongation I. Increased yield threshold limits short-term, steady state elongation rate after eexposure to salinity. J. Expt. Bot. 42:1417-1426.

Dalton, F.N., A. Maggio, and G. Piccinni. 1997. Effect of root temperature on plant response functions for tomato: Comparison of static and dynamic salinity stress indices. Plant and Soil 192:307-319.

Dalton, F.N., A. Maggio, and G. Piccinni. 2000. Simulation of shoot chloride accumulation: Separation of physical and biochemical processes governing plant salt tolerance. Plant and Soil. 219:1-11.

Dalton, F.N., A. Maggio, and G. Piccinni. 2001. Assessing the affects of solar radiation on plant salt tolerance as defined by the static and dynamic indices. Plant and Soil. 229:189-195.

De Pascale, S. and G. Barbieri. 1995. Effects of soil salinity from longterm irrigation with saline-sodic water on yield and quality of winter vegetable crops. Scientia Hort. 64:145-157.

Emerman, S.H. and T.E. Dawson. 1996. The role of macropores in the cultivation of bell pepper in salinized soils. Plant and Soil 181:241249.

Fernandez, F.G., M. Caro, and A. Cerdá. 1977. Influence of $\mathrm{NaCl}$ in the irrigation water on yield and quality of sweet pepper (Capsicum annuum). Plant and Soil 46:405-411.

Flowers, T.J. 1999. Salinization and horticultural productions. Scientia Hort. 78:1-4.

Gomez I., J.N. Pedreno, L.Moral, M.R. Iborra, G. Palacios, and J. Mataix. 1996. Salinity and nitrogen fertilization affecting the macronutrient content and yield of sweet pepper plants. J. Plant Nutr. 19:353-359. 
Greenway, H. and R. Munns. 1980. Mechanisms of salt tolerance in nonhalophytes. Annu. Rev. Plant Physiol. 31:149-190.

Gunes, A., A. Inal, and A. Alpaslan. 1996. Effect of salinity on stomatal resistance, proline, and mineral composition of pepper. J. Plant Nutr. 19:389-396.

Hachicha, M., C. Cheverry, and A. Mhiri. 2000. The impact of long-term irrigation on changes of ground water level and soil salinity in northern Tunisia. Arid Soil Res. Rehab. 14:175-182.

Handa, S., A.K. Handa, P.M. Hasegawa, and R.A. Bressan. 1986. Proline accumulation and the adaptation of cultured plant cells to water stress. Plant Physiol. 80:938-945.

Hasegawa, P.M., R.A. Bressan, J.K. Zhu, and H.J. Bohnert. 2000. Plant cellular and molecular responses to high salinity. Annu. Rev. Plant Physiol. Plant Mol. Biol. 51:463-499.

Hayashi, H., Alia, L. Mustardy, P. Deshnium, M. Ida, and N. Murata. 1997. Transformation of Arabidopsis thaliana with the codA gene for choline oxidase: Accumulation of glycinbetaine and enhanced tolerance to salt and cold stress. Plant J. 12:133-142.

Hoffman, G.J. 1990. Leaching fraction and root zone salinity control. In: K.K. Tanji (ed.). Agricultural salinity assessment and management. Amer. Soc. Civil Eng. Manual Rpt. Eng. Practice 71:237-261.

Hsiao, T.C. 1973. Plant response to water stress. Annu. Rev. Physiol. Plant Mol. Biol. 24:519-570.

Kavi Kishor, P.B., Z. Hong, G.H. Miao, C-A.A. Hu, and D.P. Verma. 1995. Overexpression of $D^{1}$-pyrroline-5-carboxylate synthetase increases proline production and confers osmotolerance in transgenic plants. Plant Physiol. 108:1387-1394.

Lauchli, A. and E. Epstein. 1990. Plant response to salinity and sodic conditions. In: K.K. Tanji (ed.). Agricultural salinity assessment and management. Amer. Soc. Civil Eng. Manual Rpt. Eng. Practice 71:113137.

Liu, J. and J.-K. Zhu. 1998. A calcium sensor homologue required for plant salt tolerance. Science, 280:1934-1945.

Long, S.L., S. Humphries, and P.G. Falkowski. 1994. Photoinhibition and photosynthesis in nature. Annu. Rev. Plant Physiol. Plant Mol. Biol. 45:633-662.

Maas, E.V. and G.J. Hoffman. 1977. Crop salt tolerance. Amer. Soc. of Civil Eng. J. Irrig. Drain. Div. 103:115-134.

Maas, E.V. and S.R. Grattan. 1999. Crop yields as affected by salinity, p. 55-108. In: R.W.Skaggs and J. van Schilfgaarde (eds.). Agricultural drainage. Amer. Soc. Agron. Monogr. 38.

Maggio, A., P.M. Hasegawa, R.A. Bressan, M.F. Consiglio and R.J. Joly. 2001. Unraveling the functional relationship between root anatomy and stress tolerance. Austral. J. Plant Physiol. 28:999-1004.

Maggio, A., F.N. Dalton and G. Piccinni. 2002a. The effects of elevated carbon dioxide on static and dynamic indices for tomato salt tolerance. Euro. J. Agron. 16:197-206.
Maggio, A., S. Miyazaki, P. Veronese, T. Fujita, J.I. Ibeas, B. Damsz, M.L. Narasimhan, P.M. Hasegawa, R.J. Joly, and R.A. Bressan. 2002b. Does proline accumulation play an active role in stress-induced growth reduction? Plant J. 31:699-712.

Meiri, A. and J. Shalevet. 1973. Crop growth under saline conditions, p. 277-290. In: B. Yaron, E. Danfors, and Y. Vaadia (eds.). Arid zone irrigation. Ecol. Studies 5. Springer-Verlag, New York.

Meyer, R.F. and J.S. Boyer. 1981. Osmoregulation, solute distribution and growth in soyabean seedlings having low water potentials. Planta 151:482-489.

Morgan, J.M. 1984. Osmoregulation and water stress in higher plants. Annu. Rev. Plant Physiol. 35:299-319.

Munns, R. 1993. Physiological processes limiting plant growth in saline soils: Some dogmas and hypotheses. Plant Cell Environ. 16:15-24.

Munns, R. and A. Termaat. 1986. Whole-plant response to salinity. Austral. J. Plant Physiol. 13:143-160.

Newman, E.I. 1966. A method of estimating the total length of root in a sample. J. Appl. Ecol. 3:139-145.

Niu, X., R.A. Bressan, P.M. Hasegawa, and J.P. Pardo. 1995. Ion homeostasis in $\mathrm{NaCl}$ stress environments. Plant Physiol. 109:735-742.

Oster, J.D. 1994. Irrigation with poor quality water. Agr. Water Mgt. 25:271-292.

Rhoades, J.D., A. Kandiah, and A.M. Mashali. 1992. The use of saline waters for crop production. Irr. Drainage Paper 48. FAO, Rome.

Ruggiero, C., S. De Pascale, and M. Fagnano. 1999. Plant and soil resistance to water flow in fababean (Vicia Faba L. major Harz.). Plant and Soil 210:219-231.

Shen, B., R.G. Jensen, and H.J. Bohnert. 1997. Mannitol protects against oxidation by hydroxyl radicals. Plant Physiol. 115:527-532.

Slavik, B. 1974. Methods of study plant water relations. Ecol. studies 9. Acad. Sci. Prague, Springer-Verlag, New York.

Tarczynski, M.C., R.G. Jensen, and H.J. Bohnert. 1993. Stress protection of transgenic tobacco by production of the osmolyte mannitol. Science 259:508-510.

Turner, N.C. 1981. Techniques and experimental approaches for the measurement of plant water status. Plant and Soil. 58:339-366.

Walinga, I., J.J. van der Lee, V.J.G. Houba, W. van Vark, and I. Novazamsky. 1995. Plant analysis manual. Kluwer Academic Publishers, Dordrecht, The Nederlands.

Yancey, P.H. 1994. Compatible and counteracting solutes, p. 81-109. In: K. Strange (ed.). Cellular and molecular physiology of cell volume regulation. CRC Press, Boca Raton, Fla.

Yancey, P.H., M.E. Clark, S.C. Hand, R.D. Bowlus, and G.N. Somero. 1982. Living with water stress: Evolution of osmolyte system. Science 217:1214-1222.

Yeo, A.R., K.S. Lee, and P.J. Izard. 1991. Short and long term effects of salinity on leaf growth in rice (Oryza sativa L.). J. Expt. Bot. 42:881-889. 